\title{
$\mathrm{X}_{2}-\mathrm{Y}_{2} \mathrm{SiO}_{5}$ における $\mathrm{Ce}^{3+}$ 発光中心の光学スペクトル
}

\author{
松井裕章* ·徐 超男 $\cdot$ 劉＼cjkstart芸·渡辺忠彦 ${ }^{\dagger}$ \\ 九州工業技術研究所無機複合材料部，841-0052 鳥栖市宿町 807-1 \\ *佐賀大学連携大学院, 841-0052 鳥栖市宿町 807-1
}

\section{Optical Spectroscopy of $\mathrm{Ce}^{3+}$-Activated $\mathrm{X}_{2}-\mathrm{Y}_{2} \mathrm{SiO}_{5}$}

\author{
Hiroaki MATSUI, ${ }^{*}$ Chao-Nan XU, Yun LIU and Tadahiko WATANABE ${ }^{\dagger}$
}

Department of Inorganic Composite Materials, Kyushu National Industrial Research Institute, 807-1, Shuku-machi, Tosu-shi, Saga $841-0052$ *Co-operation Program between KNIRI and Graduate School of Saga University, 807-1, Shuku-machi, Tosu-shi, Saga 841-0052

\begin{abstract}
Emission and excitation spectra of $\mathrm{X}_{2}-\mathrm{Y}_{2} \mathrm{SiO}_{5}$ doped with $\mathrm{Ce}^{3+}$ ions have been investigated at room temperature, in which $\mathrm{Ce}^{3+}$ ions were added by using different starting materials of $\mathrm{CeO}_{2}(\mathrm{IV})$ or $\mathrm{Ce}\left(\mathrm{NO}_{3}\right)_{3} \cdot 6 \mathrm{H}_{2} \mathrm{O}$ (III). The emission spectra were analyzed on the base of a Gaussian function to investigate the detailed optical characteristics of $\mathrm{Ce}^{3+} . \mathrm{Y}_{2} \mathrm{SiO}_{5}$ doped with $\mathrm{CeO}_{2}$ exhibited a broad spectrum with a tail in the range from 500 to $600 \mathrm{~nm}$. On the other hand, $\mathrm{Y}_{2} \mathrm{SiO}_{5}$ doped with $\mathrm{Ce}\left(\mathrm{NO}_{3}\right)_{3}$ gave a relatively sharp spectrum shortẻr than $500 \mathrm{~nm}$. With using fitting parameters based on Gaussian function, $\mathrm{Y}_{2} \mathrm{SiO}_{5}$ doped with $\mathrm{CeO}_{2}$ was found to show an additional Gaussian band around $430 \mathrm{~nm}$ in contrast to the $\mathrm{Ce}\left(\mathrm{NO}_{3}\right)_{3}$ doped one. Furthermore, the fluorescence spectra under the excitation at $330 \mathrm{~nm}$ indicated that a broad spectrum with a peak at $430 \mathrm{~nm}$ is only observed in $\mathrm{Y}_{2} \mathrm{SiO}_{5}$ doped with $\mathrm{CeO}_{2}$. Such an emission spectrum is similar to the new Gaussian band at $430 \mathrm{~nm}$ estimated from the parameter fitting. This implies that the new band actually exists, contributing to the tail of the emission spectra. These results give a new information on the occupation site of $\mathrm{Ce}^{3+}$ in the $\mathrm{X}_{2^{-}}$ $\mathrm{Y}_{2} \mathrm{SiO}_{5}$ matrix.

[Received April 27, 2000; Accepted August 23, 2000]
\end{abstract}

Key-words : $\mathrm{X}_{2}-Y_{2} \mathrm{SiO}_{5}$, Fluorescence, Ce ${ }^{3+}$ center, Oxyorthosilicate structure, Gaussian function, Luminescent site

\section{1. 緒 言}

希土類を添加した $\mathrm{Y}_{2} \mathrm{SiO}_{5}$ は紫外線や $\mathrm{X}$ 線，そして電子線照 射により，効率のよい発光特性を示す．特に， $\mathrm{Er}^{3+}$ や $\mathrm{Pr}^{3+}$ の 光学活性中心を添加した $\mathrm{Y}_{2} \mathrm{SiO}_{5}$ は, スペクトルホールバーニ ング現象を利用したホログラフィー，また $\mathrm{Y}_{2} \mathrm{SiO}_{5}: \mathrm{Ce}^{3+}$ は， 励起, 発光が電気双極子遷移でめるため, 励起緩和過程がナノ 秒と短時間であるために，シンチレーターなどに応用されてい

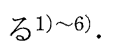

$\mathrm{Re}_{2} \mathrm{SiO}_{5}$ は $\mathrm{La}$ から $\mathrm{Tb}$ までの希土類原子によって安定する $\mathrm{X}_{1}$ 構造（空間群 $P 2_{1} / c$, 斜方晶） と, Dy から $\mathrm{Lu}$ を含む $\mathrm{X}_{2}$ 構 造（空間群 $C 2 / c$, 斜方晶）を取るオキシオルソシリケート $\mathrm{Re}_{2}\left(\mathrm{SiO}_{4}\right) \mathrm{O}$ 系に属する7) 9). ところが $\mathrm{Y}_{2} \mathrm{SiO}_{5}$ は $\mathrm{X}_{1}, \mathrm{X}_{2}$ の二 つの結晶構造を持つ物質であることが知られている. $\mathrm{X}_{1}, \mathrm{X}_{2}$ 構造は試料を合成する際の焼成温度に依存しており, $\mathrm{X}_{1}-\mathrm{Y}_{2}$ $\mathrm{SiO}_{5}$ は $1100^{\circ} \mathrm{C}$ 付近の低温領域においての及安定する。一方,

$\mathrm{X}_{2}-\mathrm{Y}_{2} \mathrm{SiO}_{5}$ は $1300^{\circ} \mathrm{C}$ 以上の高温領域において形成される ${ }^{10)}$. た，低温で安定する $\mathrm{X}_{1}-\mathrm{Y}_{2} \mathrm{SiO}_{5}$ も $1300^{\circ} \mathrm{C}$ 以上の高温になると 構造相転移を起こして, $\mathrm{X}_{2}-\mathrm{Y}_{2} \mathrm{SiO}_{5}$ が形成される.

$\mathrm{X}_{1}$ と $\mathrm{X}_{2}$ 構造の $\mathrm{Y}_{2} \mathrm{SiO}_{5}$ には，いずれも二つの結晶学的に異 なる発光サイトが存在している. 発光サイトの局所的な対称性 はすべてのサイトにおいて $C_{1}$ であるが，発光中心を取り囲む 酸素の配位数がそれぞれ異なる。酸素配位数の相違は発光特性 に大きく影響する. $\mathrm{X}_{2}-\mathrm{Y}_{2} \mathrm{SiO}_{5}: \mathrm{Er}^{3+}$ や $\mathrm{X}_{2}-\mathrm{Y}_{2} \mathrm{SiO}_{5}: \mathrm{Pr}^{3+}$ にお けるホールバーニング特性のサイト別の測定や $\mathrm{X}_{1}, \mathrm{X}_{2}-\mathrm{Y}_{2}$ $\mathrm{SiO}_{5}: \mathrm{Eu}^{3+}$ などのサイト選択別励起による発光特性が数多く 報告されている11) 14).

$\mathrm{Y}_{2} \mathrm{SiO}_{5}: \mathrm{Ce}^{3+}$ は $4 f-4 f$ 遷移により発光する $\mathrm{Er}^{3+} や \mathrm{Eu}^{3+}$ と

†現在 : 佐賀県工業技術センター，849-0932 佐賀市鍋島町大字 八戸溝 114

Present address : Industrial Technology Center of Saga, 114, Yaemizo, Nabeshima-cho, Saga-shi 849-0932
異なり, 吸收や励起帯は $5 d$ 軌道から構成され, 発光励起スぺ クトルは $5 d-4 f$ の幅広いスペクトルを示す. $\mathrm{Ce}^{3+}$ は $\mathrm{Er}^{3+}$ や $\mathrm{Eu}^{3+}$ のような鋭い励起準位を持たないため, サイト選択別励 起等の発光特性はあまり報告されておらず， Liu らが $\mathrm{X}_{1}-\mathrm{Y}_{2}$ $\mathrm{SiO}_{5}: \mathrm{Ce}^{3+}$ の発光特性から $\mathrm{Ce}^{3+}$ が二つのサイトを占有する可 能性があると示唆しているにすぎない15)。

本研究では, 発光中心の出発物質としてそれぞれ $\mathrm{CeO}_{2}$ (IV) と $\mathrm{Ce}\left(\mathrm{NO}_{3}\right)_{3} \cdot 6 \mathrm{H}_{2} \mathrm{O}$ (III) を用いて, $\mathrm{Y}_{2} \mathrm{SiO}_{5}$ に添加した試料 $\left(\mathrm{CeO}_{2}\right.$ : $\mathrm{YSO}, \mathrm{Ce}\left(\mathrm{NO}_{3}\right)_{3}$ : $\left.\mathrm{YSO}\right)$ の蛍光スペクトルと励起スペ クトルを測定した．測定されたスペクトルはガウス分布関数を 用いたシミュレーションによるスペクトル解析も加えて, $\mathrm{Ce}^{3+}$ の発光特性を詳細に検討した.

\section{2. 実験方法}

$\mathrm{Y}_{2} \mathrm{O}_{3}$ (信越化学工業製, 純度99.99\%), $\mathrm{SiO}_{2}$ (高純度化学研 究所製, $99.9 \%$ ), $\mathrm{CeO}_{2}$ (IV) (高純度化学研究所製, $99.9 \%$ ), $\mathrm{Ce}\left(\mathrm{NO}_{3}\right)_{3} \cdot 6 \mathrm{H}_{2} \mathrm{O}$ (III)（和光純薬工業製, 99.9\%) を, 組成比 が $\left(\mathrm{Y}_{2-x}, \mathrm{Ce}_{x}\right) \mathrm{SiO}_{5}$ となるようにそれぞれ秤量し, 蒸留水を用 いて $3 \mathrm{~h}$ 湿式混合した後, $90^{\circ} \mathrm{C} て ゙ 12 \mathrm{~h}$ 乾燥して, 粉砕混合を 行った。ただし, $\mathrm{Ce}\left(\mathrm{NO}_{3}\right)_{3} \cdot 6 \mathrm{H}_{2} \mathrm{O}$ の場合は $0.5 \%$ の酢酸水溶液 に溶解させ, 均一溶液を作製した後に上記の混合を行った。得 られた混合粉末を弱還元雾囲気中において $\left(\mathrm{N}_{2} / \mathrm{H}_{2}: \mathrm{H}_{2}=1.02\right.$ $\left.\%, 50 \mathrm{~cm}^{3} / \mathrm{min}\right), 1400^{\circ} \mathrm{C}$ で $12 \mathrm{~h}$ 焼成した。 還元雾囲気は $\mathrm{Ce}^{3+}$ を酸化させないために用いた。焼成された試料の結晶構造は $\mathrm{Cu} \mathrm{K} \alpha$ 線を用いた X 線回折測定により調べた.

すべての监光と励起スペクトルは $150 \mathrm{~W}$ の Xe ランプを装備 したスペクトルモノクロメーター分光蛍光光度計 (F-3010, 日立製作所製) を用いて, 室温で測定を行った. この際, 発光 におけるバンドパスは $5 \mathrm{~nm}$, 速度は $15 \mathrm{~nm} / \mathrm{min}$ の条件下にお いて測定した. 


\section{3. 結果と考察}

図 1 に発光中心 $\mathrm{Ce}^{3+}$ を添加した $\mathrm{Y}_{2} \mathrm{SiO}_{5}$ 試料の粉末 $\mathrm{X}$ 線 回折パターンを示す. $\mathrm{CeO}_{2}$ あるいは $\mathrm{Ce}\left(\mathrm{NO}_{3}\right)_{3}$ を添加した $\mathrm{Y}_{2} \mathrm{SiO}_{5}$ 試料についてすべての回折ピークが $\mathrm{X}_{2}-\mathrm{Y}_{2} \mathrm{SiO}_{5}$ に帰属 され，作製した試料は $\mathrm{X}_{2}-\mathrm{Y}_{2} \mathrm{SiO}_{5}: \mathrm{Ce}^{3+}$ の単一相を有すること が確認された.

図 2 に発光中心 $\mathrm{Ce}^{3+}(0.05 \mathrm{~mol} \%)$ を添加した試料の蛍光 スペクトルを示す．使用した励起波長は $357 \mathrm{~nm}$ であり，これ は励起スペクトルの最強ピークである. $\mathrm{CeO}_{2}: \mathrm{YSO}$ の蛍光ス ペクトルは $\mathrm{Ce}\left(\mathrm{NO}_{3}\right)_{3}: \mathrm{YSO}$ のものに比べて, 長波長側に大き な裾を示したが，いずれの蛍光スペクトルも $397 \mathrm{~nm}$ と $423 \mathrm{~nm}$ に二つのピークを持っている.この二つのピーク值は Liu らに よって報告されている值とほぼ一致している15).

図 2 に示された二つのスペクトルの大きな相違は, $500 \mathrm{~nm}$ （緑）から600 nm（赤）までの長波長側にあり, 蛍光を肉眼で 観察すると, $600 \mathrm{~nm}$ までの波長成分を持つ $\mathrm{CeO}_{2}$ : YSO は白 青, 一方, $\mathrm{Ce}\left(\mathrm{NO}_{3}\right)_{3}$ : YSO は濃青色に見える.この二つのス ペクトルの相違を明確にするために, ガウス関数を用いてスペ クトルのピーク解析を行った. 解析は最小二乗法を組み入れた ガウス関数によって精密に行った. 表 1 のピーク解析の結果か ら, 三つのガウス成分の和で蛍光スペクトルが構成されてい る. その結果を図 3 に示す. $\mathrm{CeO}_{2}: \mathrm{YSO}$ と $\mathrm{Ce}\left(\mathrm{NO}_{3}\right)_{3}: \mathrm{YSO}$

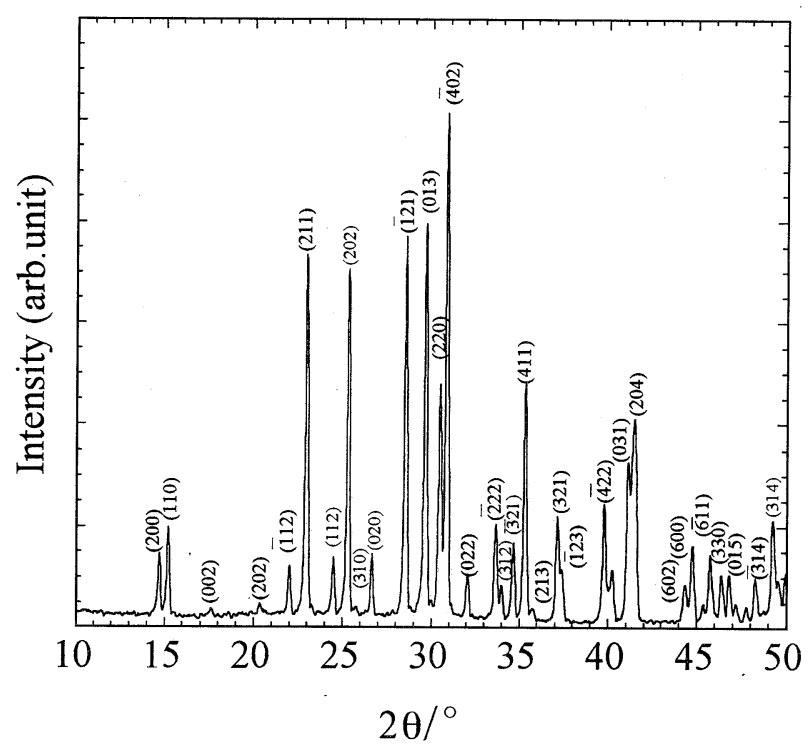

Fig. 1. X-ray diffraction pattern for $\mathrm{X}_{2}-\mathrm{Y}_{2} \mathrm{SiO}_{5}$ doped with $\mathrm{Ce}^{3+}$.
のスペクトルの相違は, 3 番目のガウスピークにあり, $\mathrm{CeO}_{2}$ を添加したものより $\mathrm{Ce}\left(\mathrm{NO}_{3}\right)_{3}$ を添加した $\mathrm{Y}_{2} \mathrm{SiO}_{5}$ のピーク強 度は約 1 けた小さいことが判明した。

著者らは長波長領域に隠されたスペクトルを探るために，発 光波長別の励起スペクトルを測定した. 図 4 に $\mathrm{CeO}_{2}$ を添加し た $\mathrm{Y}_{2} \mathrm{SiO}_{5}$ の励起スペクトルの結果を示す. $\mathrm{Ce}\left(\mathrm{NO}_{3}\right)_{3}$ : $\mathrm{YSO}$ は $\mathrm{CeO}_{2}$ : YSO と同様な励起スペクトルを示した. 図 4 より, 発光波長 $397 \mathrm{~nm}$ と $425 \mathrm{~nm}$ における励起スペクトルは, $5 d$ 軌 道が結晶場に大きく影響され，270 nm 以下の励起帯と 303 , $357 \mathrm{~nm}$ の二つのピークから成ることが分かる. 一方, 長波長 側 $(>480 \mathrm{~nm})$ に対する励起スペクトルにおいては, $330 \mathrm{~nm}$ に新しいピークが現れ，357 nm のピークが徐々に低エネル ギー側へシフトしている.この330 nm で励起された蛍光スぺ クトルを図 5 に示す. $\mathrm{CeO}_{2}$ : $\mathrm{YSO}$ の虽光スペクトルは4 $430 \mathrm{~nm}$ をピークとする幅広いスペクトルを示し, 一方, $\mathrm{Ce}\left(\mathrm{NO}_{3}\right)_{3}$ ： YSO の場合は397 nm を中心とする幅が狭いスペクトルを示し た. $\mathrm{CeO}_{2}$ : $\mathrm{YSO}$ の蛍光スペクトルは図 3 で求めた 3 番目のガ ウス関数スペクトルと同じ形状を持ち, この結果は 3 番目の スペクトルが実際に存在していることを示唆している.これに

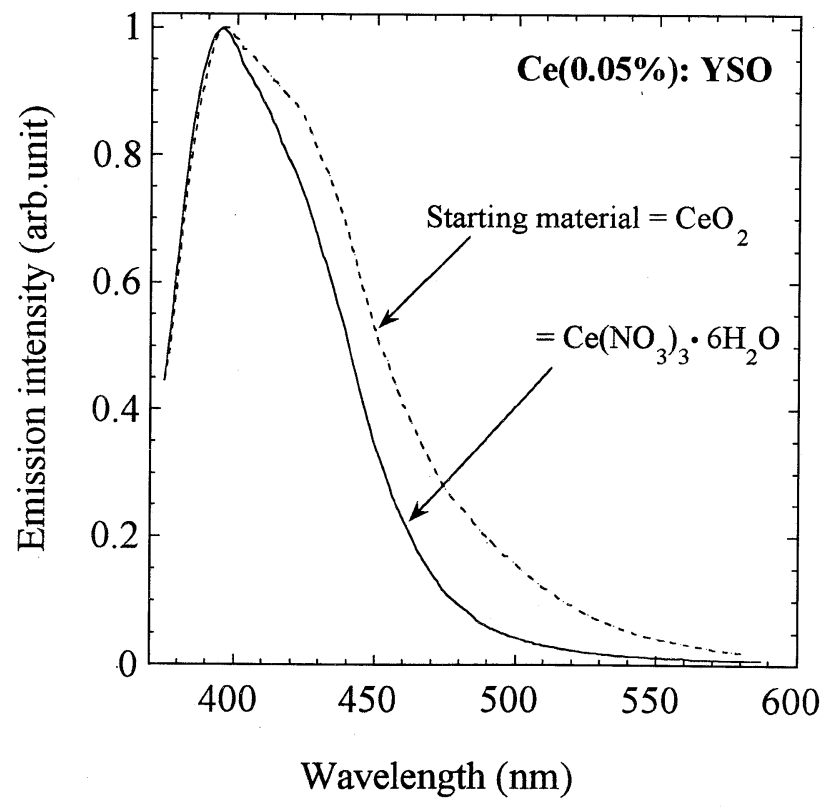

Fig. 2. Emission spectra of $\mathrm{Y}_{2} \mathrm{SiO}_{5}$ doped with $\mathrm{Ce}^{3+}$ at concentration of $0.05 \%$ excited at $357 \mathrm{~nm}$. The solid line and dashed line denote different starting materials $\mathrm{Ce}\left(\mathrm{NO}_{3}\right)_{3}$ and $\mathrm{CeO}_{2}$, respectively.

Table 1. Analysis of Emission Spectra by Decomposing into Gaussian Bands. FHWM Denotes the Full Width at Half Maximum of the Bands. Both the Spectra Can Be Decomposed into Three Gaussian Components

\begin{tabular}{lccc}
\hline $\mathrm{CeO}_{2}(0.05 \%)$ YSO & & & \\
& Amplitude & Center wavelength & FHWM \\
\hline Peak1 & 0.3392 & $390.78009 \pm 0.23792\left(25589 \mathrm{~cm}^{-1}\right)$ & 22.485 \\
Peak2 & 0.4328 & $417.52318 \pm 0.73319\left(23950 \mathrm{~cm}^{-1}\right)$ & 46.439 \\
Peak3 & 0.2684 & $432.93751 \pm 3.42427\left(23098 \mathrm{~cm}^{-1}\right)$ & 110.31 \\
& & & \\
\hline $\mathrm{Ce}\left(\mathrm{NO}_{3}\right)_{3} \cdot 6 \mathrm{H}_{2} \mathrm{O}(0.05 \%):$ YSO & & & 19.655 \\
& & & 55.609 \\
Peak1 & 0.1492 & $390.48881 \pm 0.14577\left(25608 \mathrm{~cm}^{-1}\right)$ & 141.47 \\
Peak2 & 0.3829 & $410.47476 \pm 0.75629\left(24362 \mathrm{~cm}^{-1}\right)$ & \\
Peak3 & 0.0309 & $428.81137 \pm 28.2327\left(23320 \mathrm{~cm}^{-1}\right)$ & \\
\hline$m$
\end{tabular}




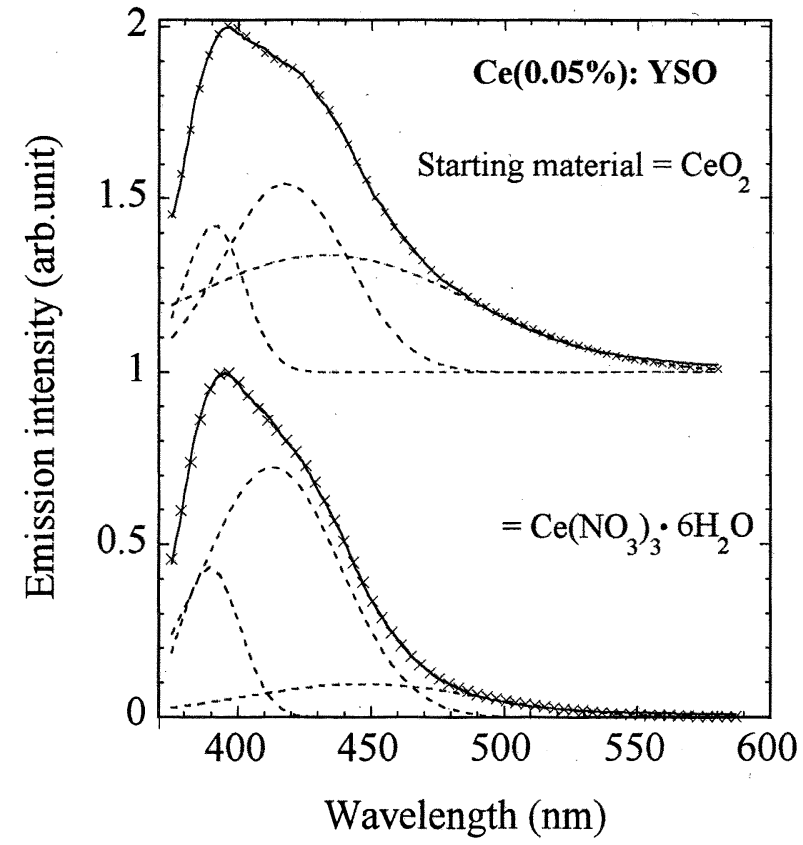

Fig. 3. Decomposition of the emission spectra of $\mathrm{Ce}(0.05 \%)$ : $\mathrm{Y}_{2} \mathrm{SiO}_{5}$ synthesized from $\mathrm{Ce}\left(\mathrm{NO}_{3}\right)_{3}$ and $\mathrm{CeO}_{2}$ as starting materials. The solid line shows the experimental data. The dashed lines and $\times$ marks stand for three Gaussian components and the calculated spectra, respectively.

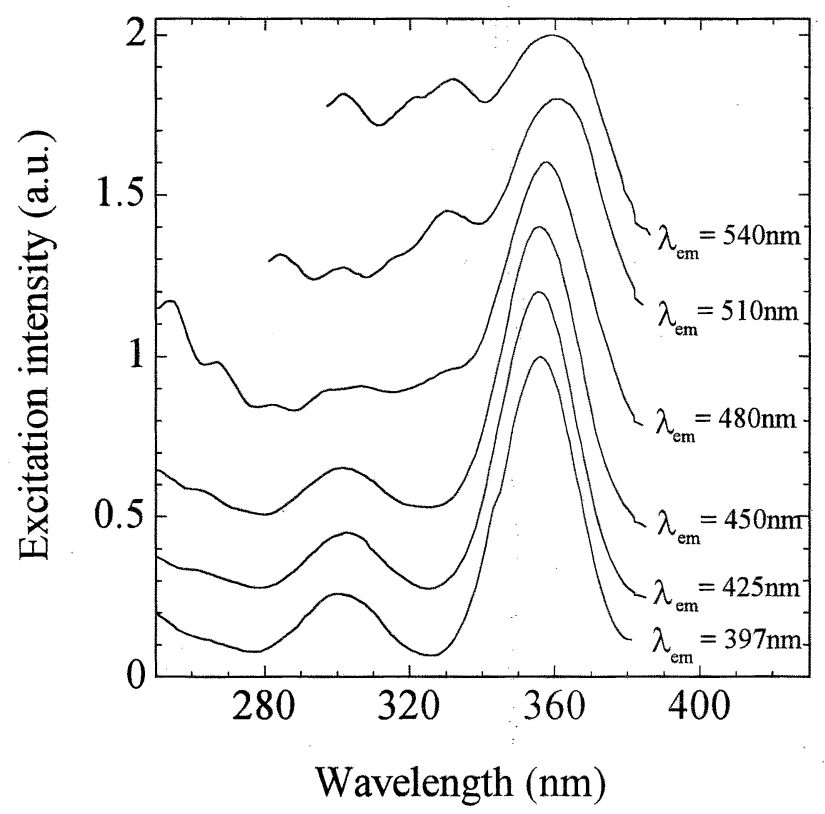

Fig. 4. Excitation spectra of $\mathrm{Ce}(0.05 \%): \mathrm{Y}_{2} \mathrm{SiO}_{5}$ prepared from $\mathrm{CeO}_{2}$ for several emission wavelengths.

対して, $\mathrm{Ce}\left(\mathrm{NO}_{3}\right)_{3}: \mathrm{YSO}$ の蛍光スペクトルは図 2 に示したも のと類似している. 図 2 で示した長波長の成分を含まない $\mathrm{Ce}$ $\left(\mathrm{NO}_{3}\right)_{3}$ : $\mathrm{YSO}$ の蛍光スペクトルには430 nm 付近のピークを観 測することができない。したがって，330 nm で励起した蛍光 スペクトルは図 2 に示した発光の長波長側の幅広い裾の原因 であると考えられる。

$\mathrm{X}_{1}$-と $\mathrm{X}_{2}-\mathrm{Y}_{2} \mathrm{SiO}_{5}$ はいずれも結晶学的に不等価な二うの $\mathrm{Y} サ$

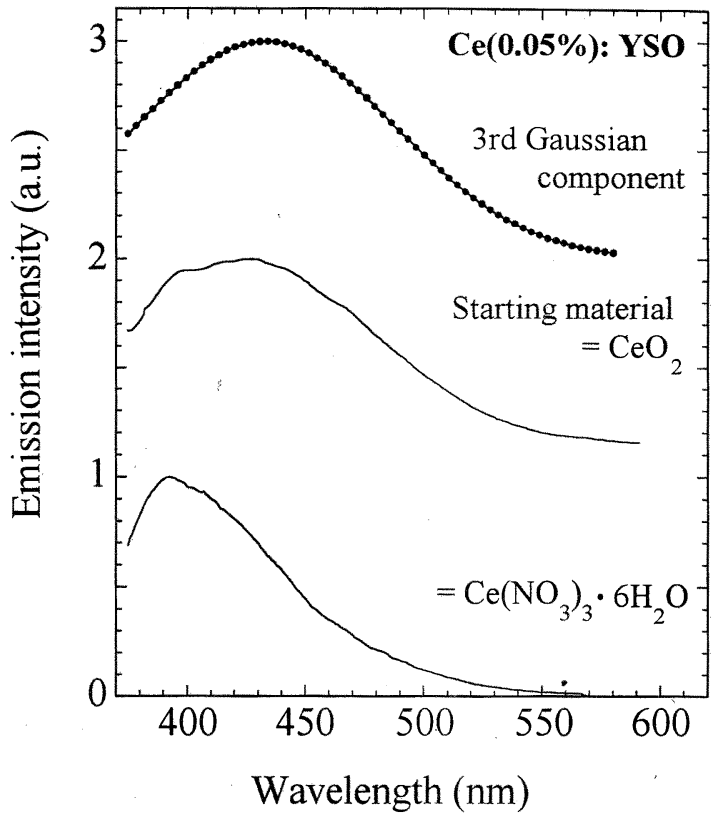

Fig. 5. Comparison between the 3rd Gaussian component and fluorescent spectra for $\mathrm{CeO}_{2}: \mathrm{Y}_{2} \mathrm{SiO}_{5}, \mathrm{Ce}\left(\mathrm{NO}_{3}\right)_{3}: \mathrm{Y}_{2} \mathrm{SiO}_{5}$ under the excitation at $330 \mathrm{~nm}$.

イトを持ち, 局所的にはすべて $C_{1}$ の低い対称性を持つ. 本研 究が対象とする高温相の $\mathrm{X}_{2}-\mathrm{Y}_{2} \mathrm{SiO}_{5}$ には二つの $C_{1}$ 対称性を持

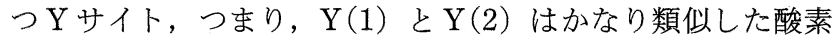
の配位数 $(\mathrm{CN})$ を持つ. $\mathrm{Y}(1)$ サイト $(\mathrm{CN}=7)$ は $\mathrm{SiO}_{4}$ に属 する五つの酸素原子と $\mathrm{SiO}_{4}$ に属さない二つの酸素原子によっ て囲まれ，また $\mathrm{Y}(2)$ ，サイト $(\mathrm{CN}=6)$ は $\mathrm{SiO}_{4}$ に属する四つ の酸素原子と $\mathrm{SiO}_{4}$ に属さない二つの酸素原子に囲まれてい $ろ^{8)}$.

$\mathrm{Ce}^{3+}$ の $5 d$ 励起状態の伝導電子のエネルギーレベルは大きく $5 d^{2} E$ と $5 d^{2} T_{2}$ に分離する. そして, スピンー軌道相互作用に より $5 d^{2} T_{2}$ は更に分離し，また $4 f$ の基底状態も ${ }^{2} F_{5 / 2}$ と ${ }^{2} F_{7 / 2}$ 軌道に分離する.よって, 発光スペクトルは $5 d^{2} T_{2}$ の最低励 起軌道から基底状態である $4 f^{2} F_{5 / 2}$ と $4 f^{2} F_{7 / 2}$ 軌道への二つの 遷移に相当する二つの成分に一般的に分かれる. $4 f^{2} F_{5 / 2}$ と $4 f^{2} F_{7 / 2}$ 軌道間のエネルギーレベルは約 $2200 \sim 2000 \mathrm{~cm}^{-1}$ とし て知られている16),17)。この軌道間のエネルギーは, $4 f$ 軌道が 外側の $5 s^{2} 5 p^{6}$ 軌道により遮蔽されているため母体依存性が少 ない。今まで, $4 f^{2} F_{5 / 2}$ と $4 f^{2} F_{7 / 2}$ のエネルギー分裂を明確に観 測できた試料としては, $\mathrm{GdAlO}_{3}: \mathrm{Ce}^{3+}$ や $\mathrm{SrGa}_{2} \mathrm{~S}_{4}: \mathrm{Ce}^{3+}$ など があり,これらの結晶ではすべて $\mathrm{Ce}^{3+}$ の発光サイトは一つで あり, ピーク分離が観測されやすいケースであった.一方, $\mathrm{Y}_{2} \mathrm{SiO}_{5}$ の場合は表 1 より, $\mathrm{CeO}_{2}: \mathrm{YSO}$ と $\mathrm{Ce}\left(\mathrm{NO}_{3}\right)_{3}: \mathrm{YSO}$ の ピーク 1, 2のエネルギー差はそれぞれ $1639 \mathrm{~cm}^{-1}$ と $1246 \mathrm{~cm}^{-1}$ であり， $4 f^{2} F_{5 / 2}$ と $4 f^{2} F_{7 / 2}$ 軌道間のエネルギー差 $2000 \mathrm{~cm}^{-1}$ と 比較して大きく異なっており，一つの発光サイトの $4 f^{2} F_{5 / 2}$ と $4 f^{2} F_{7 / 2}$ の分離に帰属することはできない。 また, 新たなピー クとして430 nm が存在しており, $\mathrm{Y}_{2} \mathrm{SiO}_{5}$ における $\mathrm{Ce}^{3+}$ の発 光サイトは, $\mathrm{Y}(1)$ と $\mathrm{Y}(2)$ に対応して二つのサイトが存在す ることが示唆された. 理想的には, 図6のモデルに示すよう に, 二つの発光サイトがそれぞれ $4 f^{2} F_{5 / 2}$ と $4 f^{2} F_{7 / 2}$ に分離す ることによって，四つの発光ピークが観測されると予想してい る. 一方, 実際のスペクトルは図 3 に示すように $397 \mathrm{~nm}$ と 


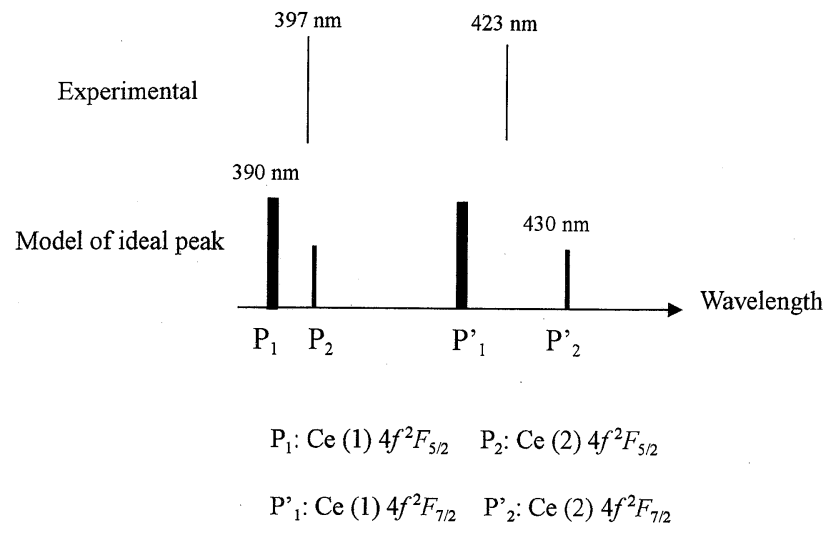

Fig. 6. Schematic draws of the observed peaks and the ideal emission peaks based on a model of two-sites for $\mathrm{Ce}^{3+}$ in $\mathrm{X}_{2}-\mathrm{Y}_{2} \mathrm{SiO}_{5}$.

$423 \mathrm{~nm}$ 付近に二つのブロードなピークが観察されるが，これ らのスペクトルから四つの分離ピークの詳細位置と形状を同定 することは困難である.四つの分離ピークを観測できなかった 理由として，励起状態である $d$ 軌道が本質的にブロードなこ と, 本研究のスペクトル測定を室温で行っているために, 二つ の発光サイトのピークが重なったと考えている.

$\mathrm{Y}_{2} \mathrm{SiO}_{5}$ への $\mathrm{Ce}^{3+}$ の添加に扔いて, 出発原料の相違が発光 スペクトルの長波長側に大きな影響を与えた。長波長側におけ る裙の原因としては, $330 \mathrm{~nm}$ で励起された $430 \mathrm{~nm}$ を中心と する幅広いスペクトルに起因する．著者らはこの現象を以下の ように考えている. $\mathrm{X}_{2}-\mathrm{Y}_{2} \mathrm{SiO}_{5}$ : $\mathrm{Ce}^{3+}$ には二つの発光サイトが 存在し, $\mathrm{CeO}_{2}: \mathrm{YSO}$ と $\mathrm{Ce}\left(\mathrm{NO}_{3}\right)_{3}$ : $\mathrm{YSO}$ に抢ける発光中心 $\mathrm{Ce}^{3+}$ の二つのサイトへの占有比率がそれぞれ異なっていると 考えられる.つまり, $\mathrm{CeO}_{2}: \mathrm{YSO}$ の方が, $\mathrm{Ce}\left(\mathrm{NO}_{3}\right)_{3}: \mathrm{YSO}$ と 比較して, $430 \mathrm{~nm}$ を中とする発光を示すサイトの占有率が 高い. $\mathrm{CeO}_{2}$ と $\mathrm{Ce}\left(\mathrm{NO}_{3}\right)_{3}$ のスペクトルの相違は，その二つの サイトに扔沙占有の比率によって決められたものと考えられ る. 二つのサイトの詳細については今後さらに実験と計算の両 方から検討する必要がある.

\section{4. 結 論}

$\mathrm{X}_{2}-\mathrm{Y}_{2} \mathrm{SiO}_{5}: \mathrm{Ce}^{3+}$ の発光スペクトルについて, $\mathrm{Ce}^{3+}$ の出発
物質としてそれぞれ $\mathrm{CeO}_{2}$ と $\mathrm{Ce}\left(\mathrm{NO}_{3}\right)_{3}$ の 2 種類を用いて比較 検討した結果，長波長側におけるスペクトルに大きな相違が見 られた. $\mathrm{CeO}_{2}$ : YSO は500 nm から600 nm の長波長成分を含 む幅広いスペクトルを示し, 一方, $\mathrm{Ce}\left(\mathrm{NO}_{3}\right)_{3}$ : YSO は500 nm 以短の比較的幅の狭いスペクトルを持つ. これらのスペクトル に対してガウス関数を用いてピーク分解した結果, $\mathrm{CeO}_{2}$ ： YSO では新たに $430 \mathrm{~nm}$ を中心とする幅広いスペクトルを持つ ことが推定され，これは $330 \mathrm{~nm}$ で励起された蛍光スペクトル とよく一致し，実際に存在していることを見出した。これらの 結果から, $\mathrm{Ce}^{3+}$ の出発原料の違いが, $\mathrm{Y}_{2} \mathrm{SiO}_{5}$ の二つの発光サ イトに占める $\mathrm{Ce}^{3+}$ の比率に大きく影響を及ぼす可能性を示唆 した.

\section{文献}

1) S. B. Alter, S. Bernet, A. Renn, E. S. Maniloff, F. R. Graf and U. P. Wild, Optics Comm., 120, 103-11 (1995).

2) C. Li, R. Moncorgé, J. C. Souriàu and Ch. Wyon, Optics Comm., 101, 356-60 (1993).

3) M. Sekita, Y. Miyazawa, T. Akahane and T. Chiba, J. Appl. Phys., 66, 373-78 (1989).

4) J. Shmulovich, G. W. Bekstresser, C. D. Brandle and A. Valentino, J. Electrochem. Soc., 135, 3141-51 (1988).

5) C. R. Ronda, V. H. Kynast, W. P. M. Dingen and H. A. M. Van Hal, J. Alloys Compounds, 192, 55-56 (1993).

6) K. Takagi and T. Fukuzawa, Appl. Phys. Lett., 42, 43-45 (1983).

7) H. Suzuki and T. A. Tombrello, IEEE Trans. Nucl. Sci., 41, 681-88 (1994).

8) H. Suzuki and T. A. Tombrello, IEEE Trans. Nucl. Sci., 40, 380-83 (1993).

9) J. Felsche, Struct. Bonding, 13, 99-197 (1973).

10) P. J. Born, D. S. Robertson and P. S. Smith, J. Mater. Sci. Lett., 4, 497-501 (1985).

11) J. Lin, Q. Su, S. Wang and H. Zhang, J. Mater. Chem., 6, 265-69 (1996).

12) M. Yin, C. Duan, W. Zhang, L. Lou, S. Xia and J. C. Krupa, J. Appl. Phys., 86, 3751-57 (1999).

13) R. W. Equall, R. C. Cone and R. M. Mactarlane, Phys. Rev. B, 52. 3963-69 (1995).

14） R. W. Mactarlane, T. L. Harris, Y. Sun, R. L. Cone and R. W. Equall, Optics Comm., 22, 871-73 (1997).

15) J. Liu, Q. Su, H. Zhang and S. Way, Mater. Res. Bull., 31, 189-96 (1996).

16) T. Hoshina and S. Kuboniwa, J. Phys. Soc. Jpn., 32, 771-77 (1972).

17) T. Hoshina and S. Kuboniwa, J. Phys. Soc. Jpn., 31, 828-39 (1971). 